\title{
ESTIMATING FLOOD INUNDATION AND THE CONSEQUENT ECONOMIC LOSSES IN THE KOILIARIS RIVER BASIN IN CRETE, GREECE
}

\author{
A-E.K. VOZINAKI \\ N.N. KOURGIALAS \\ G.P. KARATZAS*
}

Received: 02/03/12

Accepted: 25/07/12

\author{
Department of Environmental Engineering \\ Technical University of Crete \\ Polytechneioupolis, 73100 Chania
}

\section{ABSTRACT}

Local communities may experience flood events with devastating damages and economic losses. This work presents the application of an integrated method for flood loss estimation at the watershed level. The one-dimensional hydraulic model MIKE 11 was used to simulate the physical process of a flood event in a river channel and its floodplains. Flood parameters such as flood extent, floodplain water depth and flood duration were estimated. The parameter values obtained from the simulation were used for the estimation of flood loss. A grid-based mathematical model taking into account land use in the study area was used for this purpose. Such an econometric model is capable of determining flood-prone areas as well as estimating the economic losses associated with a flood event. This integrated methodology was applied to the Koiliaris River Basin in Crete, Greece.

KEYWORDS: Flood loss estimation, flood inundation, MIKE 11.

\section{INTRODUCTION}

Floods are one of the most hazardous threats to several communities affecting mainly their economies. EU directive 2007/60/EC (CEC, 2007) establishes a framework for flood risk management aiming at reducing the adverse consequences to human health, the environment, cultural heritage and economical activity associated with floods. The determination of flood prone areas and the estimation of flood damages could be a useful tool for designing the appropriate flood management plan (Kourgialas and Karatzas, 2011). Consequently, the development of a technoeconomic tool capable of directly estimating flood losses at the watershed level is of great importance.

Flood parameters such as inundation area, flood wave depth and flood duration can be simulated by several hydraulic and hydrologic models. Modelers that tend to use more sophisticated models argue that the more processes a model includes, the more accurate it will be (Bates and De Roo, 2000). However, there is also another point of view supporting that the best model to simulate flood inundation is the simplest one that provides the information required by the user whilst reasonably fitting the available data (Bates and De Roo, 2000). LISFLOOD is a simple physically based model which aims at reducing the representation of floodplain hydraulics to the minimum necessary in order to achieve acceptable accuracy when compared with available flood hydraulic data (Bates and De Roo, 2000). The performance of three different models in predicting flood inundation has been investigated in Horritt and Bates (2002). The suitability for hazard assessment of the onedimensional model HEC-RAS is compared to that of the two-dimensional models TELEMAC-2D and LISFLOOD-FP. A GIS-based approach combined with the one-dimensional hydraulic model HECRAS, instead of two- or three-dimensional models, was used by Renyi and Nan (2002) to simulate the inundation in a complex landform region of high flood hazard. A different approach to flood inundation simulation is the distributed hydrologic model IISDHM developed by Dutta et al. (2000). The model simulates flood events by combining overland and open channel network flow simulation models with evapotranspiration, unsaturated zone and saturated zone models. 
Flood damages can be classified into several categories depending on the criteria of interest (e.g., tangible and intangible, direct and indirect). Flood damages can be divided based on land use pattern and the nature of damage into rural, urban and infrastructural (Dutta et al., 2003). Urban damage includes direct damage to residential and non-residential buildings. Rural damage includes damage to agriculture products, to farm houses and to farmland infrastructure. Agricultural damage is frequently lower than urban damage, hence agricultural damage evaluation is sometimes neglected or only accounted for by using simple approaches and rough estimates (Förster et al., 2008). Stage-damage curves, although hard to derive, play a significant role in flood loss estimation. Stage-damage curves were first proposed in the USA in the 1960s and are currently internationally accepted as a standard approach to assessing urban flood damage (Smith, 1994). Urban stagedamage curves for buildings and their contents losses are also presented in Smith (1994). Dutta et al. (2003) use stage-damage curves to estimate urban and rural damages. However, in Pistrika (2009) damage curves for crops in the agricultural sector depend mainly on flood duration, the period in which flood occurs and whether the season is a growing one or not, omitting flood depth. In addition, an ESRI ArcMap tool extension which provides flood damage estimations in monetary values for specific land use types (residential, industrial and agricultural) is presented in Pistrika (2009).

The hydraulic model MIKE 11 is used to simulate a flood event at a river basin and to evaluate water depth in every grid cell of the study area. In addition, a grid-based flood loss estimation model which interacts dynamically with the hydraulic model on a cell-by-cell basis is developed. The flood loss estimation model uses the inundation area extent and the maximum water depth evaluated by the simulation model. This integrated methodology is applied to the downstream part of the Koiliaris River basin in Crete, Greece.

\section{METHODOLOGY}

\subsection{MIKE 11 hydraulic model}

The one-dimensional grid-based hydraulic model MIKE 11 is used to simulate the inundation area and the water depth in every grid cell of the study area. The MIKE 11 hydrodynamic module can simulate the hydraulics of a river system and, when applied with the dynamic wave description, solves the vertically integrated equations of continuity and momentum conservation, known as Saint Venant equations (DHI, 2011). Saint Venant equations for any cross section of an open channel are as follows:

Continuity

Equation

$$
\frac{\partial Q}{\partial x}+\frac{\partial}{\partial t}=q
$$

Momentum Equation

$$
\frac{\partial Q}{\partial t}+\frac{\partial}{\partial x}\left(\alpha \times \frac{Q^{2}}{A}\right)+g \times A \times \frac{\partial h}{\partial x}+\frac{g \times Q \times|Q|}{C^{2} \times A \times R}=0
$$

where $Q$ is the discharge $\left(\mathrm{m}^{3} \mathrm{~s}^{-1}\right), A$ the flow area $\left(\mathrm{m}^{2}\right), q$ the lateral flow $\left(\mathrm{m}^{2} \mathrm{~s}^{-1}\right), h$ the stage above datum $(\mathrm{m}), C$ : the Chezy resistance coefficient $\left(\mathrm{m}^{1 / 2} \mathrm{~s}^{-1}\right), R$ the hydraulic or resistance radius $(\mathrm{m}), \alpha$ the momentum distribution coefficient (dimensionless) and $g$ is the gravitational acceleration constant $\left(\mathrm{m} \mathrm{s}^{-2}\right)$. The solution to these equations is based on an implicit, finite difference scheme.

\subsection{Flood loss estimation model}

A grid-based mathematical model is used for flood loss estimation. It uses the same uniform grid network as the one used by the hydraulic model. MIKE 11 is used to simulate inundation area and flood water depth in every grid cell. The flood loss estimation model uses flood loss equations to estimate rural and urban damages. The calculated maximum flood water depth is supplied as input to the loss equations through stage-damage functions. These functions are used to calculate the unit damage percentage to any object (crop, building) for given water depth conditions. The typical stage-damage functions formulated for the estimation of rural and urban damages by Dutta et al. (2003) are used in this study. 
Two categories of flood damage are considered in this work, rural and urban. Rural damage to the agriculture sector includes damage to crops and vegetables and damage to farmland infrastructure. The total agriculture damage to crops and vegetables in any grid cell $(i, j)$ in $€, A D(i, j)$, is estimated based on Equations (3)-(4):

Damage to crops and vegetables

$$
\begin{gathered}
A D(i, j)=\sum_{k=1}^{n} D_{m}(i, j, k) \times C R P_{a}(i, j, k) \times L(k) \\
D_{m}=C P_{k} \times Y_{k} \times D C_{k}(i, j)
\end{gathered}
$$

where $n$ is the total number of crops. In any grid cell $(i, j), D_{m}(i, j, k)$ is the damage to crop type $k$ per unit area $\left(€ \mathrm{~m}^{-2}\right), C R P_{a}(i, j, k)$ the total area of cultivation of crop type $k\left(\mathrm{~m}^{2}\right), L(k)$ the loss factor for crop type $k$ depending on the time period of the year (\%), $C P_{k}$ the estimated cost per unit weight of crop type $k\left(€ \mathrm{~kg}^{-1}\right), Y_{k}$ the normal year yield of crop type $k$ per unit area $\left(\mathrm{kg} \mathrm{m}^{-2}\right)$ and $D C_{k}(i, j)$ the stage-damage function for crop type $k$.

The total damage to farmland infrastructure in any grid cell $(i, j)$ in $€, D_{f l}(i, j)$, is estimated as follows,

Damage to farm-land infrastructure

$$
D_{f l}(i, j)=T A(i, j) \times E C_{f l}(i, j) \times C_{f l}(i, j)
$$

where, in any cell $\operatorname{grid}(i, j), T A(i, j)$ is the total farm area $\left(\mathrm{m}^{2}\right), E C_{f l}(i, j)$ the estimated cost of complete replacement of farm infrastructure $\left(€ \mathrm{~m}^{-2}\right)$ and $C_{f l}(i, j)$ the stage-damage function.

Urban damage includes the direct damage to residential and non-residential buildings. Only damage to residential buildings is considered in this work and it is divided into four categories: structure damage, content damage, outside property damage and emergency and clean up costs. Equations (6)-(9) are used for the estimation of damages to residential buildings in any grid cell $(i, j)$ :

Structure

damage

$$
D_{s r}(i, j)=\sum_{k=1}^{r t} N R(i, j, k) \times F A(i, j, k) \times E C_{s r}(i, j, k) \times E C_{s r}(i, j, k)
$$

Content

damage

Outside

property

damage

Emergency and clean up costs

where ist is the

where $r t$ is the number of residential building types (based on building materials) and, for any grid cell $(i, j), N R(i, j, k)$ is the number of residential buildings of type $k, F A(i, j, k)$ the unit residential floor area for building type $k\left(\mathrm{~m}^{2}\right), N F(i, j)$ the number of households and $N$ the total number of residential buildings. $E C_{x}(i, j, k)$ is the unit price in present condition $\left(€ \mathrm{~m}^{-2}\right)$ for category $x, x \in$ $\{s r, c r, o p r, e r\}$ and $C_{x}(i, j)$ the depth-damage function for category $x$.

Except from the MIKE 11 model and the flood loss model, a modeling framework based on the hydrological model HSPF was employed in this study. This framework has already been successfully calibrated and validated for the Koiliaris River basin (Kourgialas et al., 2010). The time series output from the HSPF model becomes the input for the MIKE 11 model which simulates the flood inundation parameters. These parameters, namely inundation area and flood water depth, are the inputs to the flood loss estimation model. A graphical representation of the link between the models applied in this study is shown in Figure 1. 


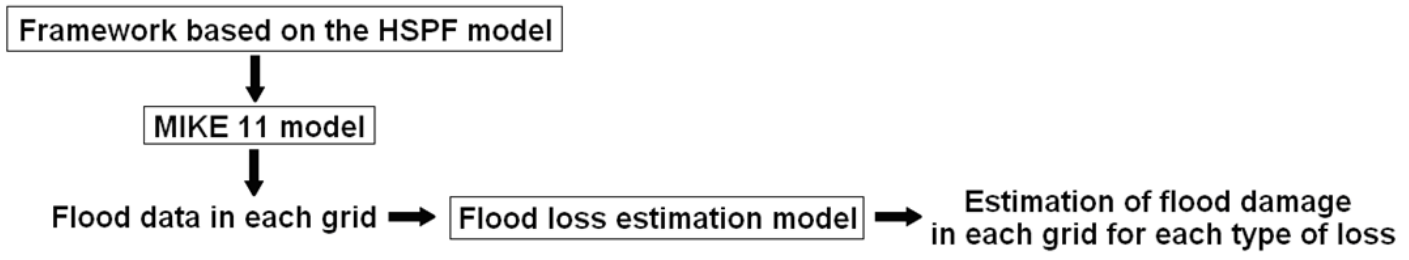

Figure 1. Model Linkage Diagram (after Kourgialas and Karatzas, 2012)

\section{METHODOLOGY APPLICATION}

\subsection{Study area}

The integrated hydraulic/loss estimation model was applied to the Koiliaris River watershed (Figure 2) which is located in the eastern part of the Chania Prefecture in Crete. Its total area is $130 \mathrm{~km}^{2}$. The total length of the hydrographic network is $36 \mathrm{~km}$. The river basin extends from the White Mountains to the coastline. The main geological formation of the river basin consists of carbonate bedrock (mainly limestone), flysch formations quaternary-neogenic and alluvial deposits. According to the Agricultural Ministry of Greece, $58 \%$ of the total land in the Koiliaris River basin is characterized as pasture (public or private), $29.4 \%$ as crops, $2.8 \%$ as settlements and roads, $8.5 \%$ as forests, $0.6 \%$ as water surfaces and $0.7 \%$ as land for other uses. Hydrologic monitoring of the Koiliaris River basin, where three hydrometric and two meteorological stations have been installed, has taken place since 2004 (Kourgialas et al., 2010). Several flood events have been observed in the basin, affecting mostly the downstream part of the watershed area. As this area is quite susceptible to erosion (Moraetis et al., 2011), a flood risk increase is expected in the future. This work investigates flood inundation and the consequent economic losses of a river segment which extends about $3 \mathrm{~km}$ from the Koiliaris outlet (Figure 2).

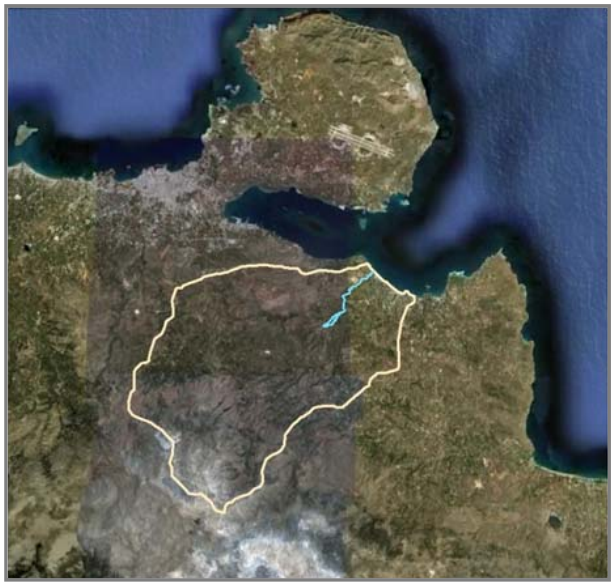

Figure 2. The Koiliaris River Basin and the river network under study

\subsection{Required Data}

\subsubsection{Data for the MIKE 11 hydraulic model}

The flood event of February 12, 2003 was simulated by using the one-dimensional hydraulic model MIKE 11. First, the river segment was designed in MIKE 11 (Figure 3). The geomorphology of the channel and of the floodplain area was specified through cross sections which lie approximately perpendicular to the direction of flow (DHI, 2011). In the present study the floodplain area was also included in the simulation process; hence the extent of each cross section includes not only the width of the river cross section but also the width of the extended floodplain area. The cross section mapping is the most significant input in river hydraulic modeling (Pramanik et al., 2010). The more the cross sectional field measurements available, the better the modeling. However, measurements are difficult and expensive to obtain and data are not readily available. Seven cross sections were used for modeling the river segment and the floodplain area (Figures 3, 4). Four of the channel cross 
sections (CS1, 2, 5, 7) were determined from field measurements and the rest (CS3, 4, 6) by using remote sensing methods. The floodplain cross section widths were determined using topographical maps (1:5000) from the Prefectural Administration of Chania. The widths of the seven cross sections are presented in Table 1.

Table 1. Width of cross sections CS1-CS7

\begin{tabular}{lcc}
\hline & Extended cross section width $(\mathrm{m})$ & Channel cross section width $(\mathrm{m})$ \\
\hline CS1 & 822.0 & 19.3 \\
CS2 & 730.0 & 48.0 \\
CS3 & 533.3 & 28.0 \\
CS4 & 450.0 & 28.0 \\
CS5 & 425.1 & 18.4 \\
CS6 & 436.3 & 18.4 \\
CS7 & 466.6 & 14.0 \\
\hline
\end{tabular}

MIKE 11 simulates the flood wave depth inside the extended cross sectional area. The calculated water depth represents the value of maximum flood wave depth along the channel and the floodplain area. Resistance values for the cross sections were specified from bibliographic data based on existing land uses (Chow et al., 1988).

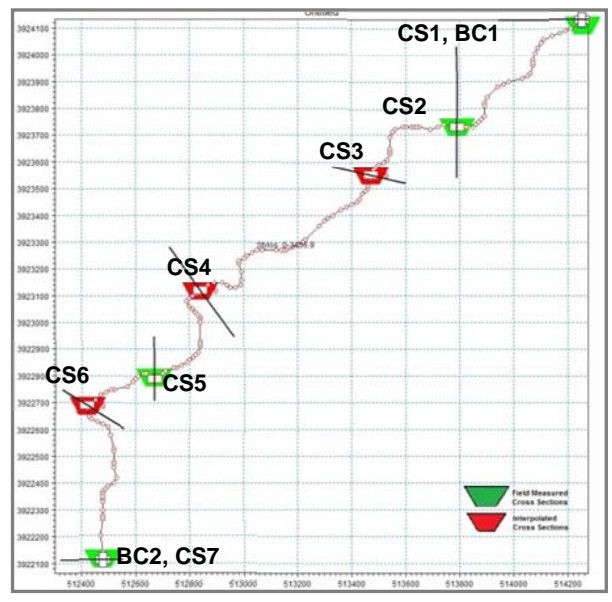

Figure 3. River channel, cross sections (CS1-7) and boundary conditions (BC1-2)

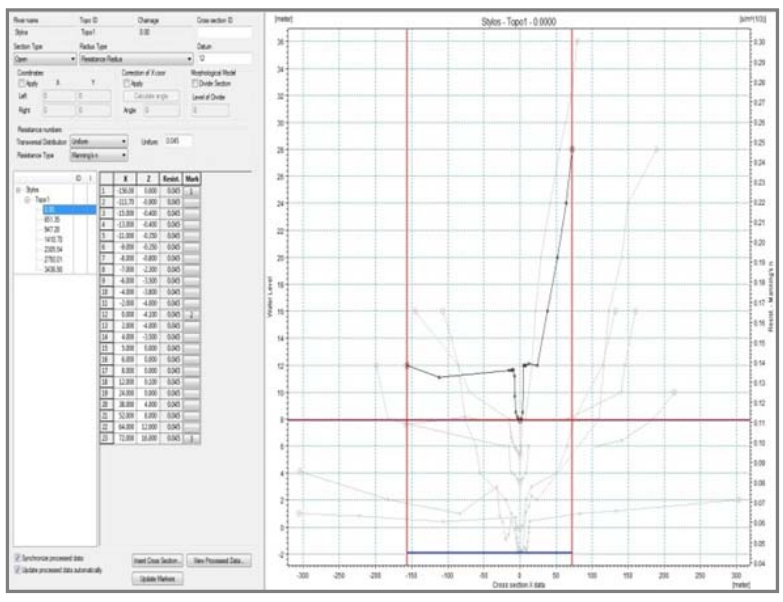

Figure 4. River cross sections

The discharge $Q$ at the upstream point of the river channel (BC2) and the water level $h$ at the outlet point downstream (BC1) were used as boundary conditions (Figure 3). The hourly time series for the boundary conditions (Figure 5) were defined using the time series output of a modeling framework based on the HSPF model. This model was developed, calibrated and validated for the Koiliaris River basin (Kourgialas et al., 2010). The flood event was simulated using a time step of 10 minutes.

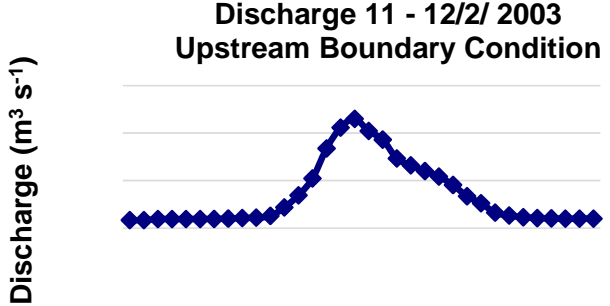

Time (hh:mm)

(a) Discharge Figure 5. Upstream and Downstream Boundary Conditions
Water Level 11 - 12/2/2003

छ Downstream Boundary Condition

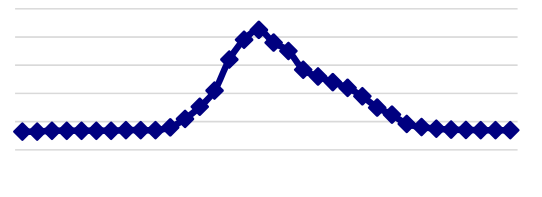

Time (hh:mm)

(b) Water Level 


\subsubsection{Flood loss simulation model data}

A land use database for the study area was necessary for the development of an accurate flood loss simulation model. Mainly agricultural activities are observed in the study area where olive groves, orchards of several kinds of fruit trees and complex cultivation patterns have been recorded. However, downstream the Koiliaris River where the topography is flat, urbanization is quite intense. Table 2 presents the land uses recorded in the study area.

Table 2. Land use database for the study area

\begin{tabular}{lll}
\hline \multirow{2}{*}{ Rural activities } & Vegetables and crops & Olive Groves $(80 \%)$ \\
\cline { 2 - 3 } & Farmland Infrastructure & Fruit trees $(12 \%)$ \\
\cline { 2 - 3 } & Fomplex cultivation patterns $(8 \%)$ \\
\hline \multirow{2}{*}{ Urban activities } & Residential buildings & $\begin{array}{l}\text { Detached single storey } \\
\text { Detached two or more storeys } \\
\text { Hotel apartments }\end{array}$ \\
\hline
\end{tabular}

\subsection{Model results}

\subsubsection{MIKE 11 model results}

Inundation extent and floodplain maximum water depth were simulated at every point of the study area. Figure 6 presents the simulated flood event of February 12, 2003 along with historical data. The simulation results are in good agreement with recorded flood data as far as the inundation area is concerned. The reported flood points fall, in general, within the simulated inundation area. There also exists a reported water depth measurement of $0.5 \mathrm{~m}$ at the flood point indicated by the yellow circle on the map of Figure 6 . The simulation result for the maximum flood water depth at the same point is $0.52 \mathrm{~m}$, very close to the reported value. Although this one verification supports the model effectiveness, any further verification of the water depth simulation results is not possible due to the lack of data. According to the simulation results, the downstream part of the river basin was affected more strongly by the flood, with water depth reaching up to four meters.

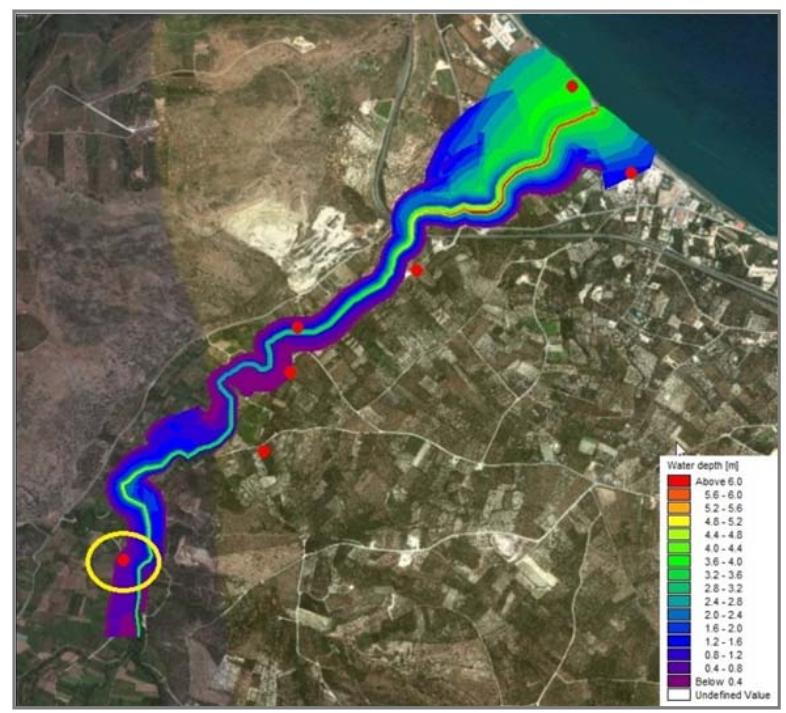

Figure 6. Verification of the simulated flood event of February 12, 2003 with historical data (red marks)

\subsubsection{Flood loss estimation model results}

The flood parameters estimated by MIKE 11 have been used as input to Equations (3)-(9) for the estimation of flood damage according to land use in every flooded grid cell. Figure 7 presents the spatial distribution of olive groves, orchards and complex cultivation patterns in the study area 
required for the estimation of agricultural damage. It also indicates the location of the two farms affected by the flood event with triangular marks. These incur farmland infrastructure damage. According to the Agricultural Insurance Organization of Greece, for wave depths less than $1 \mathrm{~m}$ $(h<1)$, the cost per unit weight of tree/crop should be associated with the produce cost, whereas for depths greater than $1 \mathrm{~m}(h>1)$, it should be associated with the cost of the entire tree/plant. Apparently, high flood waves are more damaging as they can pull down trees and destroy the entire yield. The agricultural damage, as evaluated by the model, is presented in Table 3.

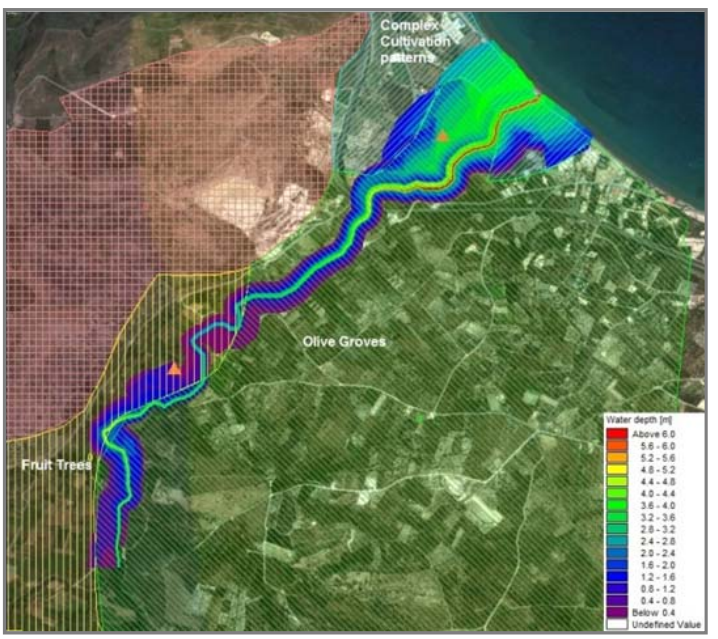

Figure 7. Inundated agricultural area and farms

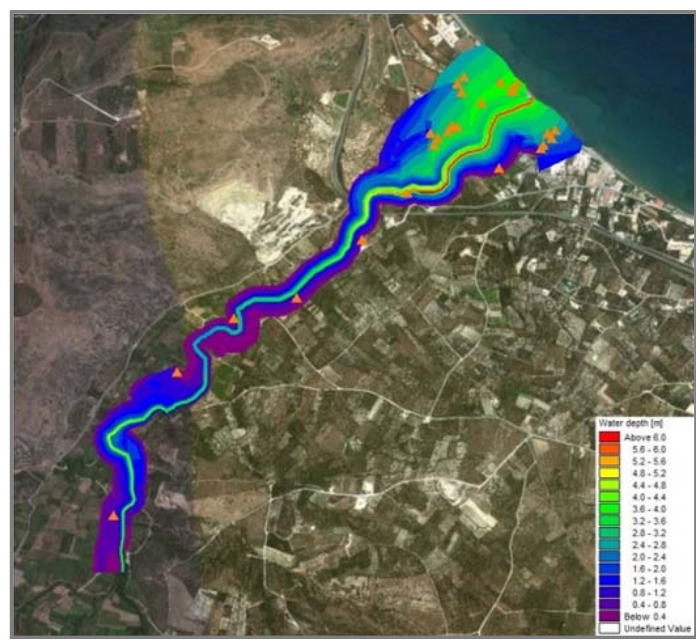

Figure 8. Inundated residential area

Table 3. Agricultural damage

\begin{tabular}{|c|c|c|c|c|c|}
\hline $\begin{array}{l}\text { Water } \\
\text { depth } \\
\text { (m) }\end{array}$ & Crop type & $\begin{array}{l}\text { Damage to crop } \\
\text { per unit area } \\
\text { (€/ha) }\end{array}$ & $\begin{array}{c}\text { Total } \\
\text { cultivation } \\
\text { area (ha) }\end{array}$ & $\begin{array}{c}\text { Loss factor } \\
\text { (\%) }\end{array}$ & $\begin{array}{c}\text { Agriculture } \\
\text { damage peI } \\
\text { crop (€) }\end{array}$ \\
\hline \multirow{3}{*}{$h<1$} & Olive Groves & 300 & 7.94 & 50 & 1,191 \\
\hline & Fruit Trees & 450 & 5.73 & 50 & 1,289 \\
\hline & $\begin{array}{c}\text { Complex } \\
\text { cultivation } \\
\text { patterns }\end{array}$ & 2,400 & 0.89 & 35 & 748 \\
\hline \multirow{4}{*}{$h>1$} & Olive Groves & 20,000 & 30.93 & 50 & 309,300 \\
\hline & Fruit Trees & 8,000 & 4.98 & 50 & 19,920 \\
\hline & $\begin{array}{l}\text { Complex } \\
\text { cultivation } \\
\text { patterns }\end{array}$ & 4,200 & 15.14 & 35 & 22,256 \\
\hline & \multicolumn{4}{|c|}{ Total agricultural damage $(€)$} & 354,704 \\
\hline
\end{tabular}

The farmland infrastructure damage, as evaluated by the model for the two flooded farms, is presented in Table 4. 
Table 4. Farmland infrastructure damage

\begin{tabular}{cccccc}
\hline $\begin{array}{c}\text { Farm } \\
\text { No. }\end{array}$ & $\begin{array}{c}\text { Water depth } \\
(\mathrm{m})\end{array}$ & $\begin{array}{c}\text { Total farm } \\
\text { area (ha) }\end{array}$ & $\begin{array}{c}\text { Farm infrastructure } \\
\text { replacement cost } \\
(€ / \text { ha) }\end{array}$ & $\begin{array}{c}\text { Stage-Damage } \\
\text { function (\%) }\end{array}$ & $\begin{array}{c}\text { Farmland } \\
\text { infrastructure damage } \\
\text { per farm }(€)\end{array}$ \\
\hline $\mathbf{1}$ & $\boldsymbol{h}<\mathbf{1}$ & 0.5 & 400,000 & 5 & 10,000 \\
\hline $\mathbf{2}$ & $\boldsymbol{h}>\mathbf{1}$ & 0.45 & 350,000 & 20 & 31,500 \\
\hline & & Total farmland infrastructure damage (€) & $\mathbf{4 1 , 5 0 0}$ \\
\hline
\end{tabular}

Damage to residential buildings includes damage to structure and contents, damage to outside property and emergency and clean up costs. The residential buildings affected by the flood event are shown in Figure 8 . All buildings are of concrete type. The estimation of the total residential building damage is shown in Table 5.

Based on the derived results, rural damage appears to be as significant as urban, residential building damage and, therefore, flood risk management is required for both sectors.

A major shortcoming of flood loss modeling is that model validation is scarcely performed and thus quality assessment of damage estimates can hardly be achieved. Based on these data problems, validation methods are often not applicable in damage modeling. The lack of accessible primary damage data could be overcome using either survey questionnaires (obtaining information related to the flooded properties and losses) and/or uncertainty analysis methods considering the potential sources of uncertainty. However, in this particular study, it can be argued that all the buildings located inside the perimeter of the flooded area determined by the simulation, have indeed been flooded. Thus, the number of actual flooded buildings equals the number of simulated flooded buildings. This argument is based on the very good agreement of the simulated and actual flood inundation area.

Table 5. Residential building damage

\begin{tabular}{|c|c|c|c|c|c|c|c|c|}
\hline $\begin{array}{l}\text { Water } \\
\text { depth } \\
\text { (m) }\end{array}$ & Building type & $N R^{*}$ & $\begin{array}{l}F A^{* *} \\
\text { (ha) }\end{array}$ & $\begin{array}{l}D_{s r} \\
(€)\end{array}$ & $\begin{array}{l}D_{c r} \\
(€)\end{array}$ & $\begin{array}{l}D_{o p r} \\
(€)\end{array}$ & $\begin{array}{l}D_{e r} \\
(€)\end{array}$ & $\begin{array}{l}\text { Total } \\
\text { residential } \\
\text { building } \\
\text { damage }\end{array}$ \\
\hline \multirow[b]{2}{*}{$h<1$} & $\begin{array}{c}\text { Detached } \\
\text { single storey }\end{array}$ & 3 & 0.060 & 12,720 & 2,480 & 58 & 40 & 15,298 \\
\hline & $\begin{array}{l}\text { Detached two } \\
\text { or more } \\
\text { storeys }\end{array}$ & 2 & 0.036 & 20,800 & 1,480 & 42 & 26 & 22,348 \\
\hline \multirow{4}{*}{$h>1$} & $\begin{array}{c}\text { Hotel } \\
\text { apartments }\end{array}$ & 3 & 0.110 & 112,200 & 22,600 & 416 & 662 & 135,878 \\
\hline & $\begin{array}{c}\text { Detached } \\
\text { single storey }\end{array}$ & 13 & 0.115 & 106,735 & 35,410 & 2,400 & 661 & 145,206 \\
\hline & $\begin{array}{l}\text { Detached two } \\
\text { or more } \\
\text { storeys }\end{array}$ & 3 & 0.048 & 47,824 & 8,370 & 138 & 138 & 56,470 \\
\hline & & \multicolumn{6}{|c|}{ Total residential building damage $(€)$} & 375,200 \\
\hline
\end{tabular}

${ }^{*} N R$ : Number of residential buildings

${ }^{* *} F A$ : Total residential floor area 


\section{CONCLUSIONS AND FUTURE WORK}

The application of an integrated method for flood loss estimation at the watershed level was presented in this work. The one-dimensional hydraulic model MIKE 11 that simulates the physical process of a flood event was combined with a grid-based mathematical model that estimates flood loss. The simulation results were in good agreement with the recorded historical data for the flood event of February 12, 2003. The simulation results were imported into the flood loss estimation model and the total flood loss downstream the Koiliaris River basin was estimated to $771,404 €$ for agricultural and urban damages. Damage to the agricultural sector accounts for $51.4 \%$ of the total damage and the rest $48.6 \%$ accounts for damage to the urban sector. The economy of the Koiliaris River basin is mainly based on the production of crops and vegetables. Based on the loss estimation presented in this work, both sectors were equally affected by the flood event. Hence, flood risk management plans are required in both sectors. Furthermore, as the downstream part of the Koiliaris River basin is more vulnerable to flooding, this area should receive greater attention in flood protection management plans. The development of flood damage assessment tools is important for watersheds prone to this hazard.

One-dimensional flood modeling is the simplest approach and may not be accurate, especially in case where field data are sparse. Since the topographical representation of a channel is time consuming and expensive, other methods are required for the simulation of flood inundation. Twodimensional hydrological modeling, which takes into consideration additional information, may improve the accuracy of the modeling approach. The extension of the presented methodology by using more sophisticated hydraulic models is planned in future work.

\section{ACKNOWLEDGEMENTS}

This research has been co-financed by the European Union (European Social Fund-ESF) and Greek national funds through the Operational Program "Education and Lifelong Learning" of the National Strategic Reference Framework (NSRF)-Research Funding Program: Heracleitus II. Investing in knowledge society through the European Social Fund.

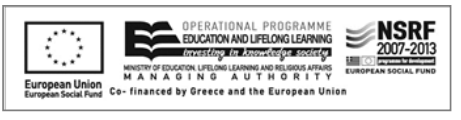

\section{REFERENCES}

Bates P.D. and De Roo A.P.J. (2000), A simple raster-based model for flood inundation simulation, Journal of Hydrology, 236(1-2), 54-77.

CEC (Commission of European Communities) (2007), Directive 2007/60/EC of the European Parliament and of the Council 23 October 2007 on the Assessment and Management of Flood Risk, Brussels: Official Journal of the European Communities 6.11.2007 L 288.

Chow V.T., Maidment D.R. and Mays L.W. (1988), Applied Hydrology, McGraw-Hill, New York.

DHI (2011), MIKE 11, A Modelling System for River and Channels, Reference Manual.

Dutta D., Herath S. and Musiake K. (2000), Flood inundation simulation in a river basin using a physically based distributed hydrologic model, Hydrological Processes, 14(3), 497-519.

Dutta D., Herath S. and Musiake K. (2003), A mathematical model for flood loss estimation, Journal of Hydrology, 277(1-2), 24-49.

Förster S., Kuhlmann B., Lindenschmidt K.-E. and Bronstert A. (2008), Assessing flood risk for a rural detention area, Nat. Hazards Earth Syst. Sci., 8, 311-322.

Horrit M.S. and Bates P.D. (2002), Evaluation of 1D and 2D numerical models for predicting river flood inundation, Journal of Hydrology, 268(1-4), 87-99.

Kourgialas N.N., Karatzas G.P. and Nikolaidis N.P. (2010), An integrated framework for the hydrologic simulation of a complex geomorphological river basin, Journal of Hydrology, 381(3-4), 308-321.

Kourgialas N.N. and Karatzas G.P. (2011), Flood management and a GIS modeling method to assess flood-hazard areas-a case study, Hydrological Sciences Journal, 56(2), 212-225.

Kourgialas N.N. and Karatzas G.P. (2012), A hydro-economic modelling framework for flood damage estimation and the role of riparian vegetation, Hydrological Processes, DOI: 10.1002/hyp.9256.

Moraetis D., Stamati F., Kotronakis M., Fragia T., Paranychnianakis N. and Nikolaidis N.P. (2011), Identification of hydrologic and geochemical pathways using high frequency sampling, REE 
aqueous sampling and soil characterization at Koiliaris Critical Zone Observatory, Crete, Applied Geochemistry, 26, S101-S104.

Pistrika A. (2009), Flood damage estimation based on flood simulation scenarios and a GIS platform, Proceedings of EWRA $7^{\text {th }}$ International Conference "Water Resources Conservancy and Risk Reduction Under Climatic Instability", Limassol (Cyprus), 419-427.

Pramanik N., Panda R.K. and Sen D. (2010), One dimensional hydrodynamic modeling of river flow using DEM extracted river cross-section, Water Resources Management, 24(5), 835-852.

Renyi L. and Nan L. (2002), Flood area and damage estimation in Zhejiang, China, Journal of Environmental Management, 66(1), 1-8.

Smith D.I. (1994), Flood damage estimation - a review of urban stage-damage curves and loss functions, Water SA, 20(3), 231-238. 